\title{
Effect of Local and Global Scour on Lateral Response of Single Piles in Different Soil Conditions
}

\author{
Yasser E. Mostafa \\ Department of Irrigation and Hydraulics, Faculty of Engineering, Ain Shams University, Cairo, Egypt \\ Email: yasser_mostafa@eng.asu.edu.eg
}

Received March 4, 2012; revised April 18, 2012; accepted April 25, 2012

\begin{abstract}
Marine structures, offshore platforms and bridge piers are usually supported on foundation piles. These piles are subjected to lateral loading due to wind, waves and currents. Piles installed in marine or river environments are susceptible to scour depending on wave and current characteristics and soil types. In this paper, the effect of local and global scour on behavior of laterally loaded piles installed in different soil conditions has been investigated. Finite element model (FEM) using the software program PLAXIS and Winkler model using the software program LPILE were used in the analyses. Different parameters were investigated such as soil types, scour depth, scour hole dimension, pile material, submerged condition, magnitude of lateral load and load eccentricity. The results showed that scour has a significant impact on piles installed in sand and a less significant impact on piles installed in clay. Global scour has a significant impact on pile lateral displacement and bending stresses. The effect of scour is more significant if piles are subjected to large lateral loads due to the nonlinear response of pile-soil system. Effect of scour of stiff clayey soils on piles is more pronounced than that of soft clayey soils.
\end{abstract}

Keywords: Piles; Lateral Loading; Scour; Sand; Clay

\section{Introduction}

Bridge piers and marine structures like jetties, seawalls and offshore structures can fail due to severe scour caused by currents and waves. Numerous publications are found in the literature for investigating scour around piles, especially in cohesionless soils and a smaller number of publications investigating scour in cohesive soils.

Coastal structures are often subjected to waves, storm surge, erosion and scour. Global scour refers to a general lowering of the ground surface over a wide area.

The ultimate scour depth depends on the diameter of obstruction, flow Froude number, shear stress and soil characteristics. It has been documented that local scour depth in sandy soils $\left(d_{s}\right)$ is 1.3 times pile diameter (d) with a mean of 0.7 [1]. In other words, the maximum scour depth is about 2 times the pile diameter (i.e., $\mathrm{d}_{\mathrm{s}} / \mathrm{d}=2$ ). Global scour exposing piles due to storm surge events has been reported in the literature (for example, Robertson et al. [2]). Scour around piles in cohesive soils has been presented in [3-5]. For scour in soft clays, the ultimate scour depth ratio $\mathrm{d}_{\mathrm{s}} / \mathrm{d}$ is 0.75 to 1 [6].

A very limited number of publications regarding the effect of scour on the behavior of piles are found in the literature. A thorough review of available literature on the topic showed that there is no research related to full- scale field or lab tests on scour effects on laterally loaded piles in sand.

Kishore et al. [6] and [7] conducted experimental tests on small diameter PVC and aluminum piles to study the influence of scour on laterally loaded single piles installed in soft clay. Lin et al. [8] investigated the scour effect on the response of laterally loaded single piles installed in sand considering the stress history of remaining sand.

This paper aims at reducing the gap of knowledge found in the literature in this subject. Different parameters were investigated such as soil types (medium dense sand, soft clay and stiff clay), scour depth, scour hole dimension, pile material (concrete piles and steel piles), submerged condition, magnitude of lateral load and load eccentricity. Finite element model (FEM) using the software program PLAXIS and Winkler model using the software program LPILE were used in the analysis. Comparison with experimental tests found in the literature for scour around piles installed in soft clay was conducted.

\section{Mechanics of Scour}

The flow velocity approaching a vertical cylindrical pile decreases from a maximum at the free surface to zero at bed level at the upstream pile face. If the pressure field induced by the pile is sufficiently strong, it causes a three- 
dimensional separation of the boundary layers which roll up ahead of the pile to form the horse-shoe vortex [9]. Flow patterns in the wake of the cylinder also influence the scour. Scour occurs when the drag and lift forces applied by the eroding flow exceed the gravitational, frictional, and/or cohesive forces acting to hold the particles together [5].

Figure 1 shows a sketch of global scour and local scour. The vertical effective stress at a point depends on the soil weight above that point. In case of global scour, the effective soil pressure at all depths is reduced with the weight of scoured soil. In case of local scour depth, the effective stress near the pile and near the scour hole base is reduced. At a very large depth, impact of scour hole on the effective soil pressure diminishes [10].

\section{Scour in Cohesionless Soils}

In this paper, the effect of scour on pile behavior was investigated using finite element model and Winkler model. Finite element model (FEM) was conducted using the software program PLAXIS. The soil was modeled as Mohr-Coulomb model and finite element mesh was generated by 15 -node triangular elements. The scour hole was modeled approximately as a conical shape with trapezoidal shape cross section. Figure 2 shows an example of deformed mesh and scour hole.

The results from FEM were also compared with those from the software LPILE which is widely used in practice. The software program LPILE is based on a nonlinear Winkler foundation model, utilizing displacement-based beam elements for the pile and nonlinear spring elements which represent the lateral response ( $p$-y curves) of the surrounding soil. Pile and sand characteristics used in the analysis are provided in Table 1. For all analysis, pile head was assumed to be free.

\subsection{Effect of Local Scour and Global Scour}

Effect of local and global scour around piles installed in sandy soils was investigated. Scour hole due to local scour was modeled using PLAXIS. Scour hole depth equivalent to twice the pile diameter was considered $\left(d_{s} / d=2\right)$. Global scour was modeled through removing the soil layer of thickness equal to twice the pile diameter. This

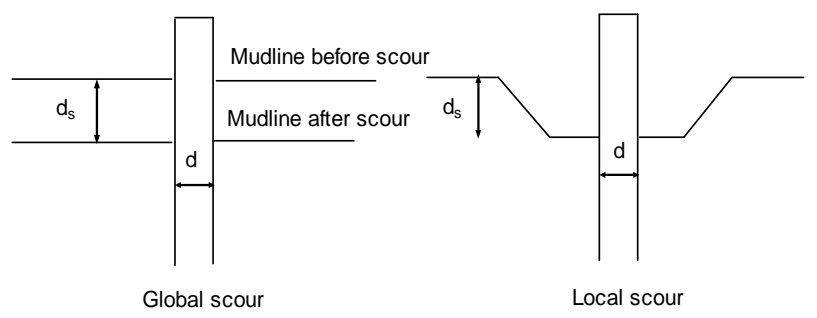

Figure 1. Sketch showing local and global scour.

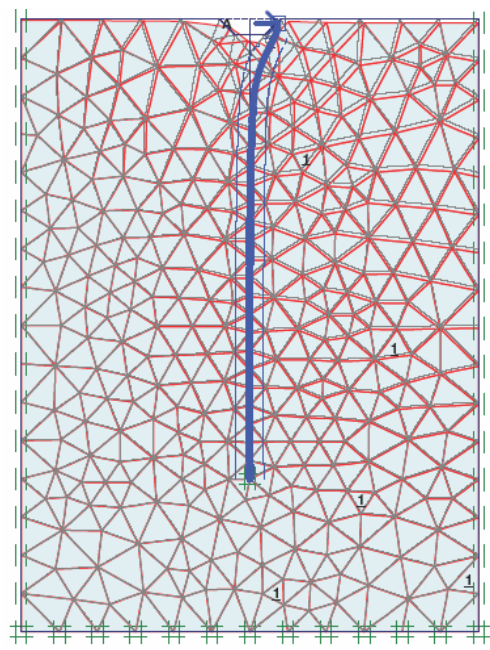

Figure 2. FEM of pile and soil showing deformed mesh and scour hole (displacements are exaggerated for illustration).

Table 1. Pile and sand characteristics used in the analysis.

\begin{tabular}{cccccccccc}
\hline Pile type & $\begin{array}{c}\mathrm{d} \\
(\mathrm{m})\end{array}$ & $\begin{array}{c}\mathrm{L} \\
(\mathrm{m})\end{array}$ & $\begin{array}{c}\mathrm{A} \\
\left(\mathrm{m}^{2}\right)\end{array}$ & $\begin{array}{c}\mathrm{I}_{\mathrm{p}} \\
\left(\mathrm{m}^{4}\right)\end{array}$ & $\mathrm{E}_{\mathrm{p}} / \mathrm{E}_{\mathrm{s}}$ & $\begin{array}{c}\gamma_{\mathrm{s}} \\
\mathrm{kN} / \mathrm{m}^{3}\end{array}$ & $v_{\mathrm{s}}$ & $\begin{array}{c}\mathrm{V}_{\mathrm{s}} \\
\mathrm{m} / \mathrm{s}\end{array}$ \\
\hline Steel pipe & 0.5 & 30 & 0.01944 & $5.77 \times 10^{-4}$ & 2000 & $35^{\circ}$ & 17 & 0.3 & 150 \\
Concrete & 0.5 & 30 & 0.19635 & $3.07 \times 10^{-3}$ & 250 & $35^{\circ}$ & 17 & 0.3 & 150 \\
\hline
\end{tabular}

represents the case of soil erosion at a wide distance around the pile as shown in Figure 1. Local scour represents the case of scour hole around pile. The hole was modeled in PLAXIS as conical shape with trapezoidal cross section assuming scour depth equal to $2 \mathrm{~d}$ and the scour hole base extends around the pile at a distance $\left(\mathrm{L}_{\mathrm{sb}}\right)$ varying between 0 and $\mathrm{d}$. The hole side slope was assumed to be $45^{\circ}$. The same pile and soil parameters presented in Table 1 were used in the analysis. Different lateral loads were applied at the pile head. Global scour was modeled in PLAXIS and LPILE. It should be noted that local scour with different hole dimensions can not be modeled by LPILE.

Figure 3 shows the normalized pile head displacement $(y / d)$ versus lateral load at pile head for case of no scour, global scour and local scour with different scour hole dimensions. No significant difference was found if lateral load (F) is lower than $100 \mathrm{kN}$. For higher lateral loads, the difference becomes more considerable as pile-soil system behaves nonlinearly.

Ultimate lateral pile capacity when scour is neglected was found to be $1100 \mathrm{kN}$. The ultimate lateral pile capacity if local scour hole base $\left(\mathrm{L}_{\mathrm{sb}}\right)$ equals 0 and $\mathrm{d}$ was found to be $1000 \mathrm{kN}$ and $700 \mathrm{kN}$, respectively. For case of global scour $\left(\mathrm{L}_{\mathrm{sb}}=\infty\right)$, ultimate lateral pile capacity was calculated to be $500 \mathrm{kN}$, which is about $45 \%$ of the ultimate capacity if scour is neglected. Ultimate lateral pile capacity in case of global scour is about $50 \%$ to $70 \%$ of that in case of local scour depending on the scour hole 


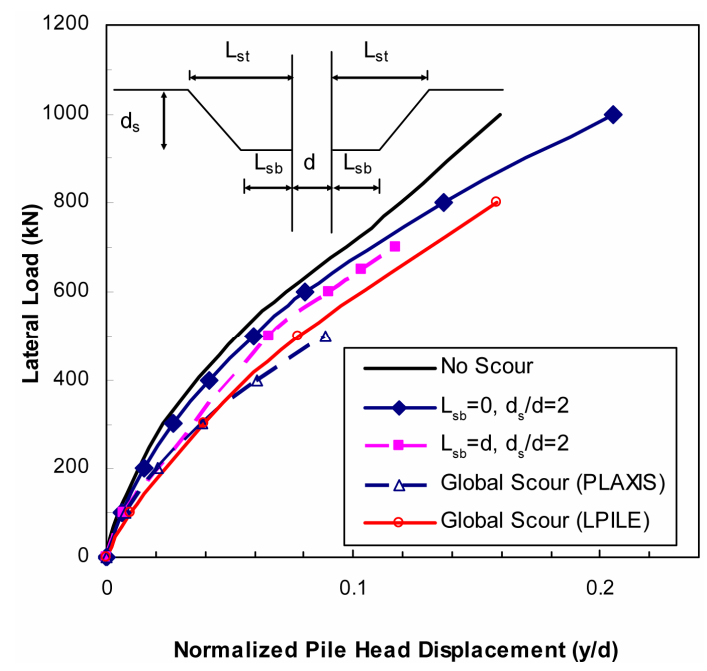

Figure 3. Normalized pile head displacement versus lateral load for case of no scour, global scour and local scour with different scour hole dimension.

dimensions. For case of global scour, it was noted that results using PLAXIS and LPILE agree reasonably.

Figure 4 shows the displacement and bending moment along pile length for case of no scour, local scour $\left(\mathrm{L}_{\mathrm{sb}}=\right.$ $0)$, local scour $\left(\mathrm{L}_{\mathrm{sb}}=\mathrm{d}\right)$ and global scour $\left(\mathrm{L}_{\mathrm{sb}}=\infty\right)$ when applying a lateral load of $500 \mathrm{kN}$ at ground surface. It was found that the wider the scour hole base the larger the pile head displacement and bending moment. For case of scour hole with base dimensions $\mathrm{L}_{\mathrm{sb}}=0$ and $\mathrm{L}_{\mathrm{sb}}=$ $\mathrm{d}$, pile head displacement increased by about $14 \%$ and $25 \%$, respectively. It was found that global scour increased the pile head displacement by about $70 \%$ compared to pile with no scour.

Figure 5 shows a comparison of displacement and bend- ing moment along pile length computed using FEM (PLAXIS) and Winkler model (LPILE) when applying a lateral load of $500 \mathrm{kN}$ at ground surface. Two cases were considered; no scour and global scour. The bending moment at pile head for the two cases was found to be very similar but the maximum positive bending moment computed using LPILE was found to be higher than that computed using PLAXIS.

\subsection{Effect of Scour Depth}

A parametric study was conducted to investigate the effect of scour depth in lateral behavior of single steel pipe piles. A relative scour depth $\left(\mathrm{d}_{s} / \mathrm{d}\right)$ of 1, 1.3, 2 and 3 was selected. Figure 6 presents lateral displacement, shear force, bending moment and soil reaction along pile length. For the same lateral load, lateral pile head displacement increases significantly with increase in scour depth. For $\mathrm{d}_{\mathrm{s}} / \mathrm{d}=1,1.3,2$ and 3 , the maximum pile head displacement increases compared to the case of no scour by about $37 \%, 51 \%, 87 \%$ and $155 \%$, respectively. For case of $d_{s} / d$ $=2$, bending moment at pile head increases by about $48 \%$ compared to that for pile without scour. Also, maximum bending moment along pile length increases by about $60 \%$ over that for case of no scour. Location of maximum shear and bending moment occurs at a deeper depth when scour depth increases. For a pile without scour, maximum bending moment is located at about 6 pile diameters (6d). For a pile with scour equivalent to twice the pile diameter $\left(d_{s} / d=2\right)$, maximum bending moment is located at about 7.2d. The increase in bending moment due to scour can require piles with larger pile rigidity or higher steel grade to ensure that bending stresses do not exceed the pile yield stress.

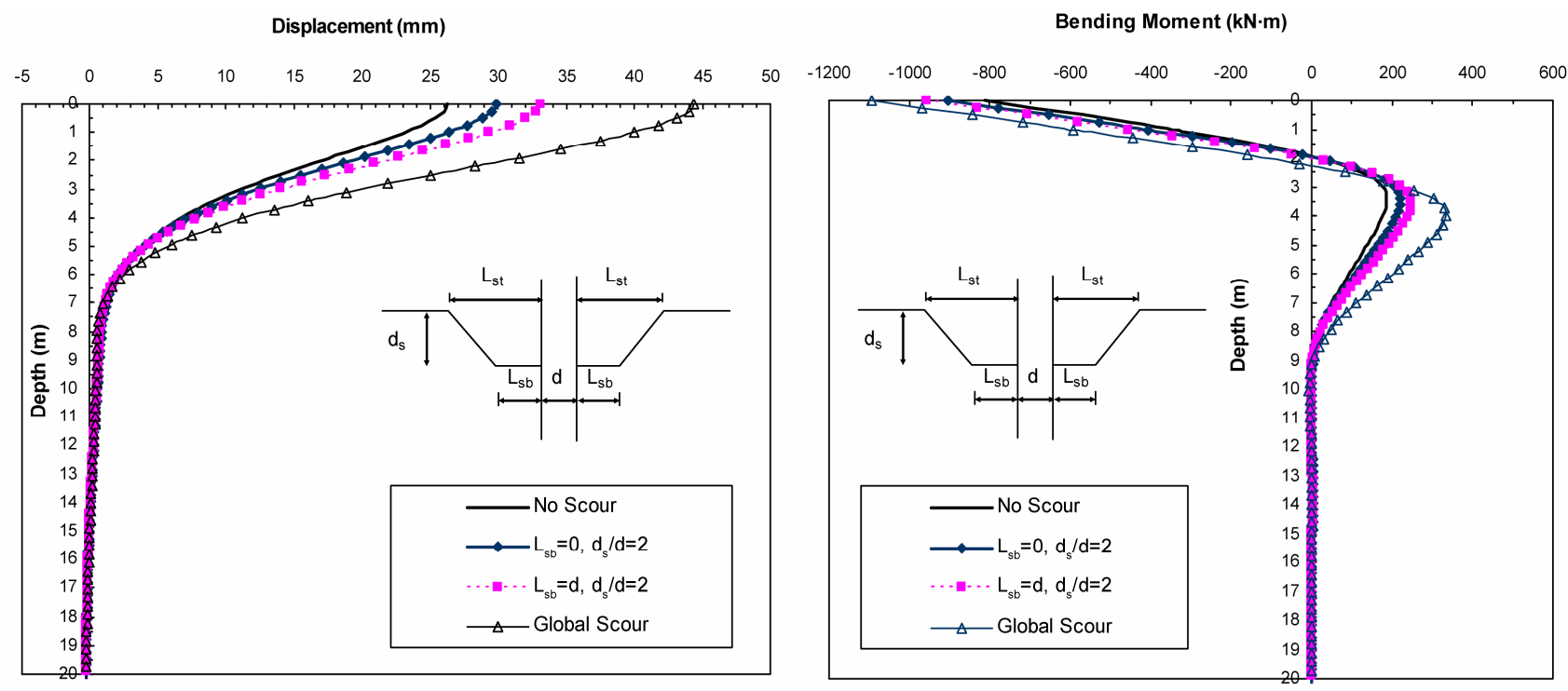

Figure 4. Lateral pile head displacement and bending moment along pile length for case of local scour with different hole dimensions and global scour modeled using PLAXIS ( F = $500 \mathrm{kN})$. 

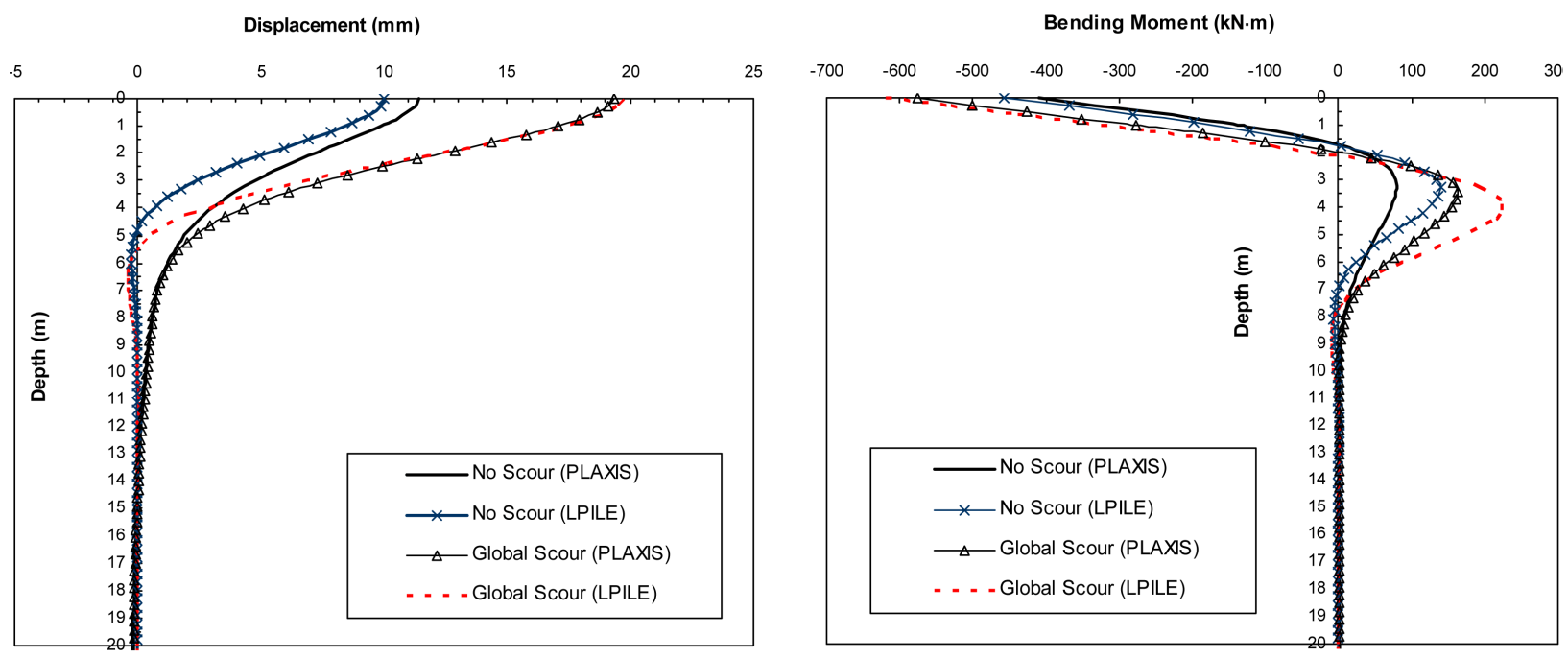

Figure 5. Comparison between FEM \& LPILE results for displacement and bending moment along pile length $(\mathrm{F}=500 \mathrm{kN})$.

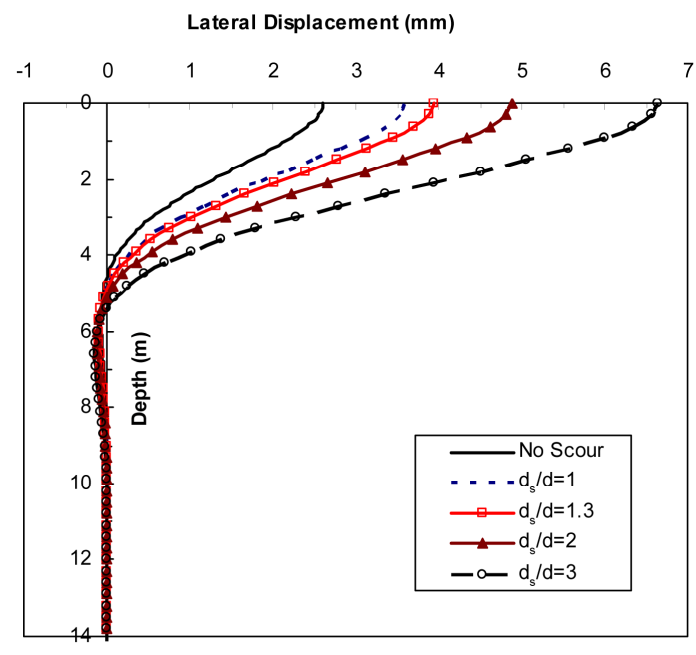

(a)

Bending Moment (kN.m)

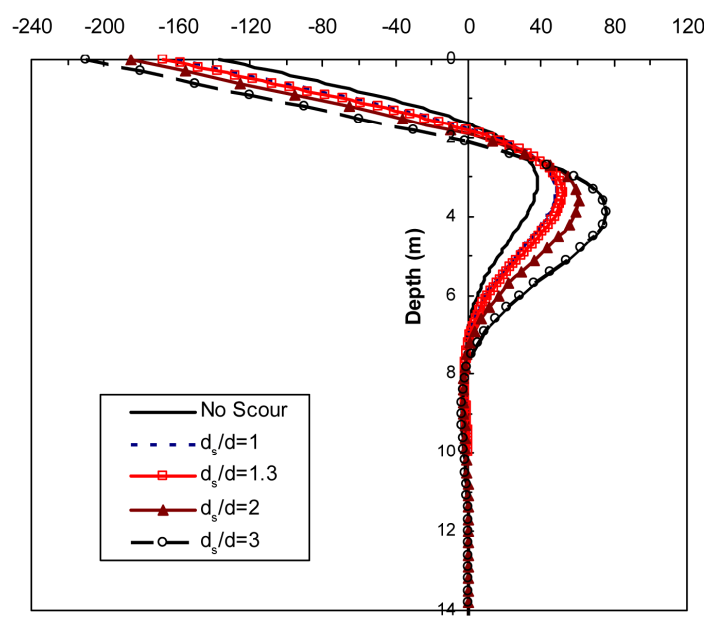

(c)

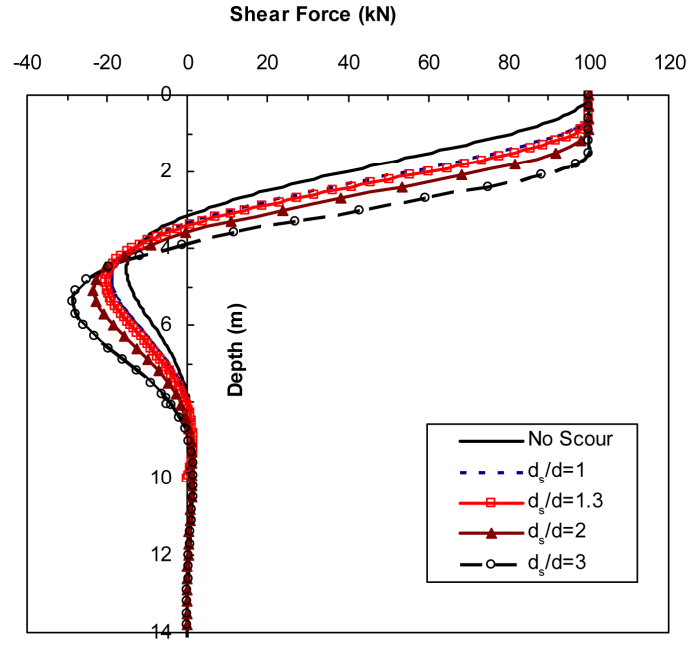

(b)

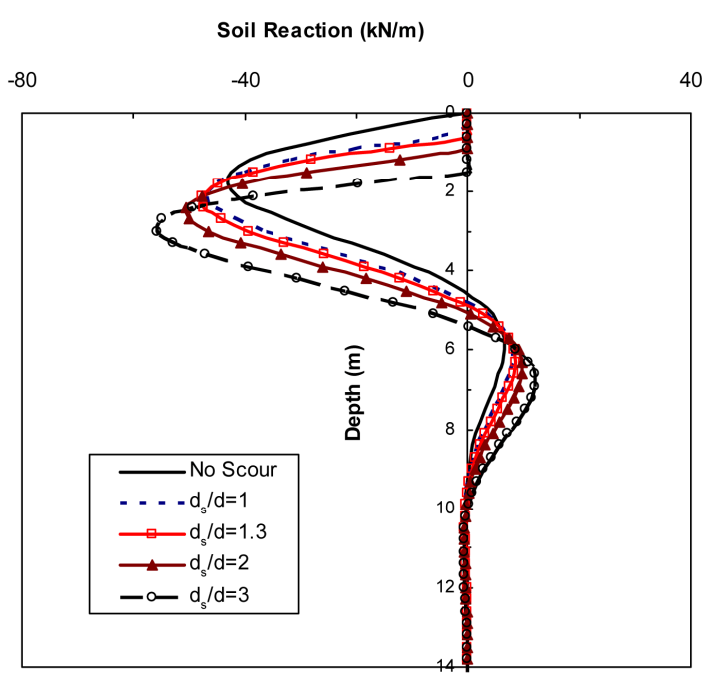

(d)

Figure 6. Effect of scour depth on lateral response along pile length: (a) Lateral pile displacement; (b) Shear force; (c) Bending moment; (d) Soil reaction $(\mathrm{F}=100 \mathrm{kN})$. 


\subsection{Effect of Lateral Load Magnitude and Pile Material Type}

Figure 7 shows the relationship between normalized pile head displacement (y/d) and lateral load (F) applied at ground surface. It can be seen that $\mathrm{y} / \mathrm{d}$ increases nonlinearly with the increase in lateral loads. A comparison between case of pile without scour "no scour" and case of pile with scour equivalent to twice the pile diameter " $\mathrm{d}_{\mathrm{s}} / \mathrm{d}$ $=2$ " indicates that pile head deflection increases within the range of about $85 \%$ to $97 \%$ for steel piles and increases within the range of about $97 \%$ to $106 \%$ for concrete piles. Also, it is shown that lateral capacity of steel piles is larger than that of concrete piles.

Figure 8 shows the variation of bending moment along pile length neglecting and considering scour. Two values of lateral load $(\mathrm{F})$ are presented $(\mathrm{F}=100 \mathrm{kN}$ and $\mathrm{F}=500$ $\mathrm{kN}$ ). For lateral load of $100 \mathrm{kN}$ (linear zone), bending moment for a pile with scour increases by about $35 \%$ over the case of a pile without scour. By applying a lateral load of $500 \mathrm{kN}$ (nonlinear zone), the bending moment increases by about $56 \%$ over that for case of "no scour". At $\mathrm{F}=500 \mathrm{kN}$, location of maximum bending moment along pile length occurs at a deeper depth (8.4d) compared to that for case of "no scour" $(7.2 \mathrm{~d})$. The effect of scour appears to be more significant with large lateral loads.

\subsection{Effect of Submerged Condition}

Generally, marine soils are under submerged condition. Finite element modeling was used to evaluate different water levels above ground surface. It was found that existence of water level at or above pile head provides similar results to the cases were groundwater is below the scour hole depth.

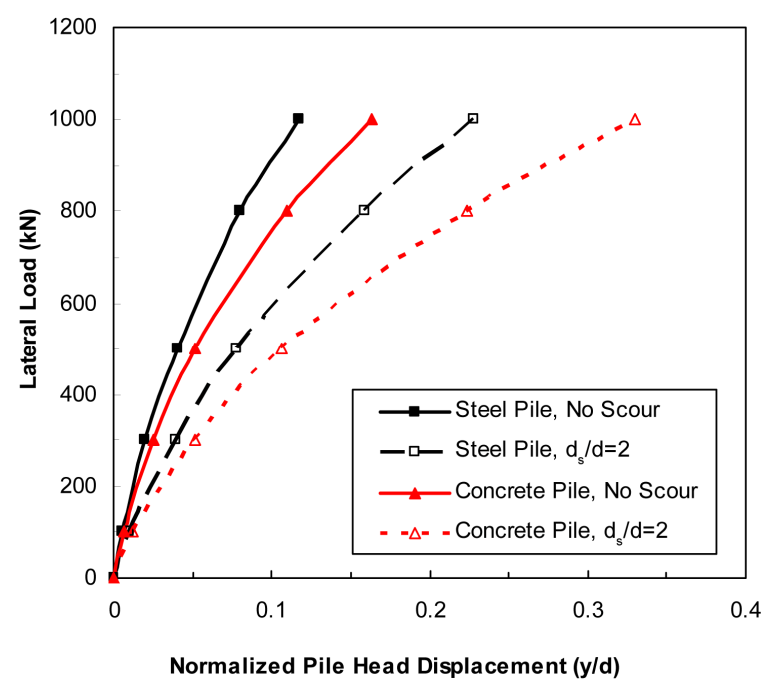

Figure 7. Load versus normalized pile head displacement for steel and concrete piles neglecting and considering scour.

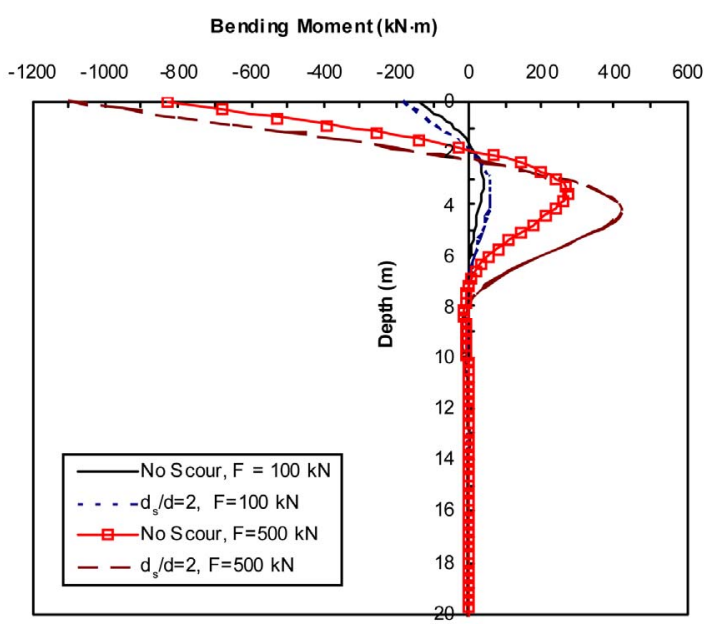

Figure 8. Variation of bending moment with depth for steel piles neglecting and considering scour.

\subsection{Effect of Load Eccentricity}

In most of marine structures and bridge piers supported on piles, lateral loads are applied above the bed surface and this can induce large bending moments. A load eccentricity (e) equivalent to twice the pile diameter was considered to determine the effect of eccentricity on the lateral behavior of piles in case of neglecting scour and considering scour. A global scour depth equivalent to twice pile diameter $\left(d_{s} / d=2\right)$ was considered. Figure 9 indicates that significant reduction in lateral pile capacity is observed when load eccentricity is applied. For example, at $y / d$ ratio of 0.2 , lateral pile capacity decreases from $1300 \mathrm{kN}$ to $400 \mathrm{kN}$ due to load eccentricity on pile without scour. At the same $\mathrm{y} / \mathrm{d}$ ratio of 0.2 , lateral pile capacity decreases from about $900 \mathrm{kN}$ to $300 \mathrm{kN}$ due to load eccentricity on pile with scour. It is noted that global scour reduced lateral pile capacity by about $25 \%$ to $30 \%$. When load is applied above ground surface, a small increase in lateral load causes considerable increase in pile deflection.

Figure 10 shows the variation of bending moment with depth when load eccentricity and scour are considered. It is noted that eccentricity significantly increases the bending moment. For the same lateral load of $100 \mathrm{kN}$, which represents the linear zone, and load eccentricity $(\mathrm{e} / \mathrm{d}=2)$, scour increases the maximum bending moment by about $44 \%$. The maximum bending moment for case of neglecting scour and considering scour occurred at about $3.6 \mathrm{~d}$ and $5.4 \mathrm{~d}$, respectively.

\section{Scour in Cohesive Soils}

\subsection{Comparison with Laboratory Experiments}

To the author's knowledge, no field tests were conducted to investigate the effects of scour on laterally loaded piles installed in clay. Kishore et al. [7] conducted laboratory 


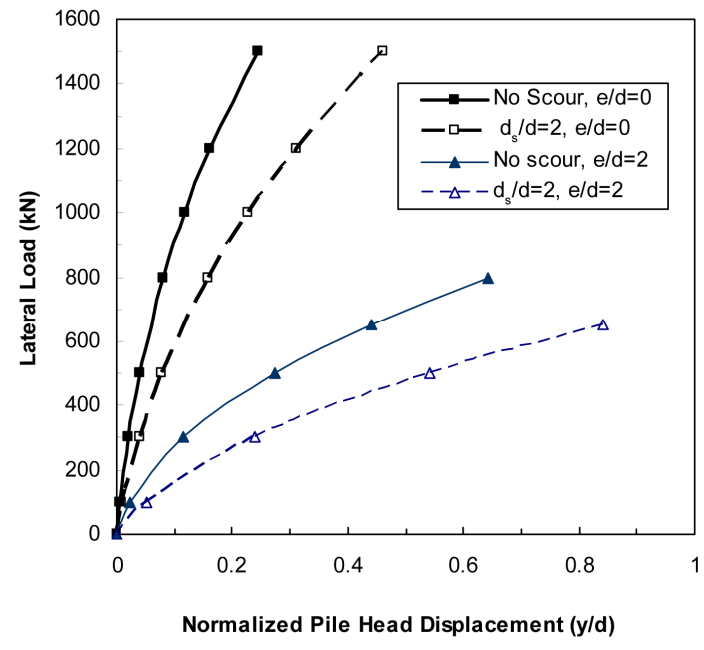

Figure 9. Load versus normalized pile head displacement (y/d) considering the effect of load eccentricity (e).

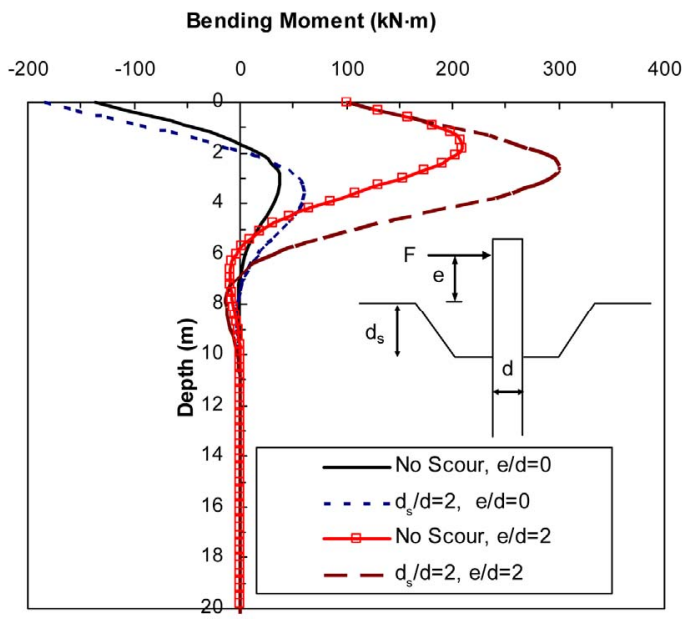

Figure 10. Variation of bending moment with depth considering load eccentricity e/d $(F=100 \mathrm{kN})$.

experiments on small size PVC and aluminum piles embedded in soft marine clay subjected to scour. Models of single piles of $50 \mathrm{~mm}$ diameter and $1000 \mathrm{~mm}$ length were used in the testing.

To validate LPILE results, a comparison with results from experimental work of Kishore et al. [7] was conducted. Flexural rigidity $\mathrm{E}_{\mathrm{p}} \mathrm{I}_{\mathrm{p}}=6.5 \times 10^{9}$ and soil modulus $\mathrm{E}_{\mathrm{s}}=870 \mathrm{kPa}$ were considered. For calibration, cohesive strength $\left(\mathrm{C}_{\mathrm{u}}\right)$ of $7 \mathrm{kPa}$ and $\varepsilon_{50}$ of 0.02 was used.

Figure 11 shows a comparison between LPILE results and lab test results of Kishore et al. [7] for aluminum piles subjected to lateral load (F) of $120 \mathrm{kN}$ and eccentricity ratio (e/d) of 3. Two cases were considered; case of pile without scour "no scour" and case of pile with scour depth equivalent to pile diameter $\left(\mathrm{d}_{\mathrm{s}} / \mathrm{d}=1\right)$. It can be seen that LPILE and experimental results are in good agreement. LPILE slightly overestimated the bending moment along depth.

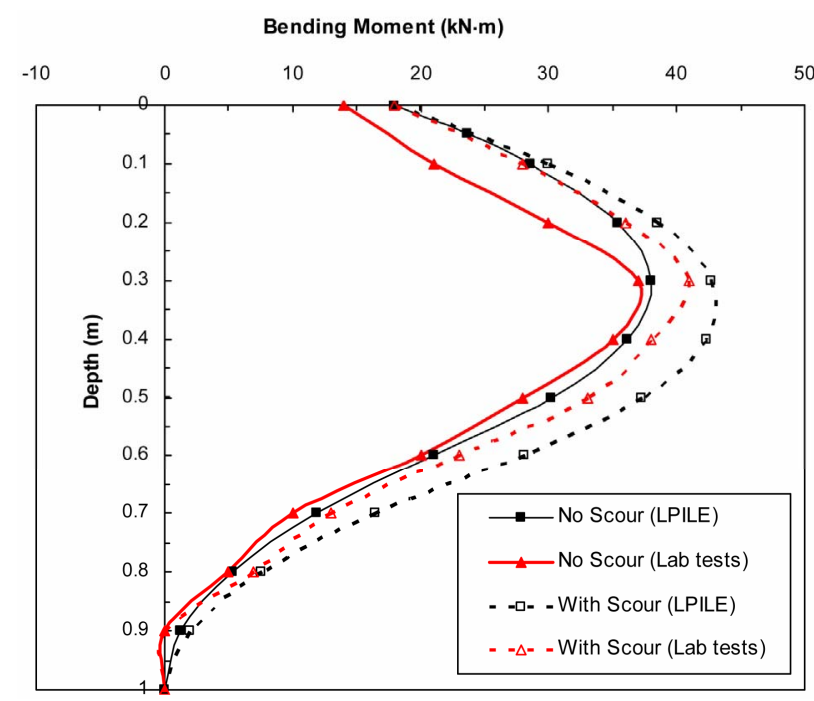

Figure 11. Comparison between LPILE results and lab test results of Kirshore et al. [7] at $\mathrm{F}=120 \mathrm{~N}$ and $\mathrm{e} / \mathrm{d}=3$.

\subsection{Numerical Analysis}

As the experimental work of Kishore et al. [7] was conducted in small size aluminum and PVC piles, it is essential to extend the investigation to cover lateral load behavior of piles installed in marine environment with pile characteristics and material type normally used in practice. In this paper, the effect of scour on steel piles installed in soft clay and stiff clay is investigated using the software program LPILE and FEM using PLAXIS. The used pile and soil characteristics are presented in Table 2. The results are presented in the following subsections.

\subsubsection{Effect of Soil Strength}

The effect of soft clay and stiff clay was investigated. Maximum scour depth equivalent to pile diameter was considered $\left(d_{s} / d=1\right)$. Also, the case of neglecting scour was also considered for comparison.

Figure 12 shows the relationship between lateral load and normalized pile head displacement $(\mathrm{y} / \mathrm{d})$. The variation of bending moment along pile length is shown in Figure 13. For steel piles installed in soft clay, scour increases lateral pile head displacement by about $20 \%$. For steel piles installed in stiff clay, scour increases lateral pile displacement by about $36 \%$ compared to that for pile without scour.

It is concluded from Figures $\mathbf{1 2}$ and $\mathbf{1 3}$ that the effect of scour is more pronounced for piles installed in stiff clay compared to piles installed in soft clay.

\subsubsection{Effect of Lateral Load}

Different values of lateral load were applied to investigate the effect of lateral loading magnitude on steel piles installed in soft clay and stiff clay. Figure 12 indicates that the relationship between lateral load (F) and normalized 
Table 2. Steel pile and clay characteristics used in the analysis.

\begin{tabular}{ccccccccccc}
\hline Clay Type & $\mathrm{d}(\mathrm{m})$ & $\mathrm{L}(\mathrm{m})$ & $\mathrm{A}\left(\mathrm{m}^{2}\right)$ & $\mathrm{I}_{\mathrm{p}}\left(\mathrm{m}^{4}\right)$ & $\mathrm{E}_{\mathrm{p}} / \mathrm{E}_{\mathrm{s}}$ & $\mathrm{C}_{\mathrm{u}}(\mathrm{kPa})$ & $\gamma_{\mathrm{s}} \mathrm{kN} / \mathrm{m}^{3}$ & $v_{\mathrm{s}}$ & $\varepsilon_{50}$ & $\mathrm{~V}_{\mathrm{s}} \mathrm{m} / \mathrm{s}$ \\
\hline Soft Clay & 0.5 & 30 & 0.01944 & $5.77 \mathrm{E}-4$ & 30000 & 10 & 16 & 0.3 & 0.02 & 50 \\
Stiff Clay & 0.5 & 30 & 0.01944 & $5.77 \mathrm{E}-4$ & 2000 & 50 & 17 & 0.3 & 0.005 & 200 \\
\hline
\end{tabular}

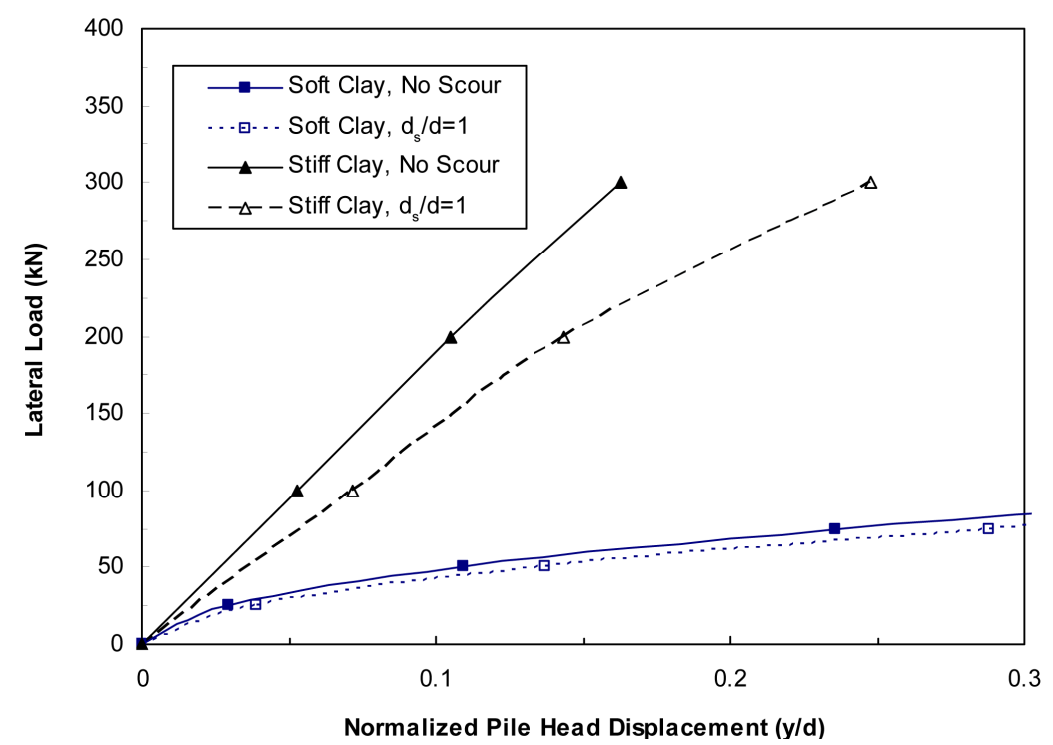

Figure 12. Lateral load versus normalized pile head displacement for piles in soft clay and stiff clay with and without scour.

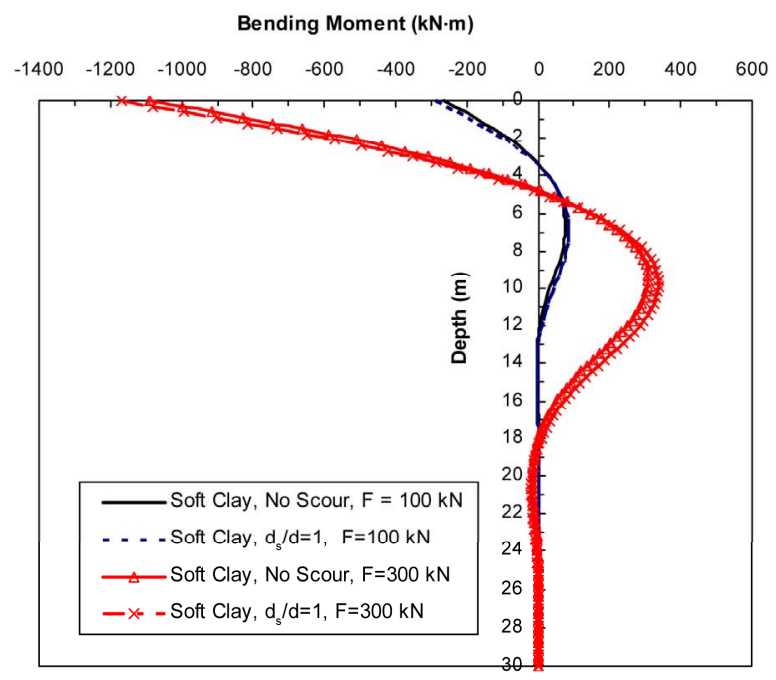

(a)

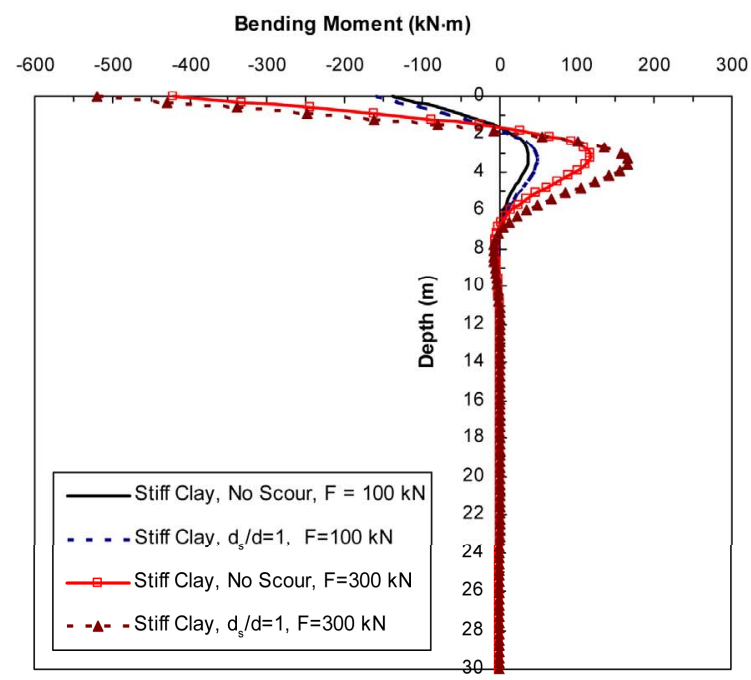

(b)

Figure 13. Bending moment profile along pile length at different loading levels: (a) Soft clay; (b) Stiff clay.

pile head displacement $(\mathrm{y} / \mathrm{d})$ is highly nonlinear for piles installed in soft clay. For stiff clay, the relationship between $\mathrm{F}$ and $\mathrm{y} / \mathrm{d}$ is linear if $\mathrm{y} / \mathrm{d}$ ratio varies between 0 and 0.1 and then nonlinear response starts to appear especially if scour is considered.

It is noted from Figure 13(a) that scour around piles installed in soft clay slightly increases the bending moment. This effect is negligible in the linear zone $(\mathrm{F}=100$ $\mathrm{kN})$. An increase of only $9 \%$ occurs in the nonlinear zone
$(\mathrm{F}=300 \mathrm{kN})$.

By applying lateral load $(\mathrm{F})$ of $100 \mathrm{kN}$ and $300 \mathrm{kN}$, variation in bending moment along pile length is provided in Figure 13. Lateral loads (F) of $100 \mathrm{kN}$ and 300 $\mathrm{kN}$ represent linear zone and nonlinear zone, respectively. For soft clay, the bending moment dramatically increases at the nonlinear zone as shown in Figure 13(a). The bending moment at pile head reaches about $1170 \mathrm{kN}$. Assuming the pile is Grade 4 steel with a yield stress of 450 
$\mathrm{MPa}$, the equivalent moment causing the pile to yield is about $1039 \mathrm{MPa}$, which is slightly lower than bending moment at pile head indicating that the pile experienced yield due to that loading magnitude. By applying a lateral load (F) of $100 \mathrm{kN}$ at ground surface, the maximum bending moment occurs at a depth equal to $13 \mathrm{~d}$ below ground surface. By increasing the lateral load to $300 \mathrm{kN}$, the maximum bending moment occurs at a depth equal to $19 \mathrm{~d}$ below ground surface. The maximum bending moment along pile length occurs at a much deeper depth for piles installed in soft clay.

Figure 13(b) shows that scour around piles installed in stiff clay increases the maximum value of bending moment by about $17 \%$ due to applying a lateral load of $100 \mathrm{kN}$ (linear zone). At nonlinear zone $(\mathrm{F}=300 \mathrm{kN})$, the difference in bending moment is about $42 \%$. Therefore, the scour effect is more significant when higher loading magnitude is applied, especially for stiff clay soils. It is also noted that the first point of zero moment occurs at a depth equal to about $3.6 \mathrm{~d}$ and that maximum bending moment occurs at a depth equal to $6.6 \mathrm{~d}$ below ground surface and then the bending moment drops to zero at a depth of about $15 \mathrm{~d}$.

\subsubsection{Effect of Flooding}

Generally, marine soils are under submerged conditions. To investigate the effect of water above ground surface, the software program PLAXIS was used to evaluate if existence of water above ground surface will have impact on the pile behavior. Figure 14 shows bending moment profile when flooding is considered and neglected. It was found that existence of water level at or above ground surface provides similar results to the cases were groundwater is below the scour hole depth. Similar conclusions were reached through experimental work conducted by Kishore et al. [6].

\subsubsection{Effect of Load Eccentricity}

For a steel pile installed in soft clay, a load eccentricity (e) equivalent to twice pile diameter was considered (e/d $=2$ ). Figure 15 indicates that significant reduction in lateral capacity is observed when load eccentricity is applied. For example, at $\mathrm{y} / \mathrm{d}$ ratio of 0.2 , lateral pile capacity is reduced from about $70 \mathrm{kN}$ to $25 \mathrm{kN}$ if scour is neglected (i.e., reduction by about $64 \%$ ). If scour is considered, at the same $y / d$ ratio of 0.2 , the lateral pile capacity is reduced from about $62 \mathrm{kN}$ to $20 \mathrm{kN}$ (i.e., reduction by about $68 \%)$.

By applying the same lateral load of $50 \mathrm{kN}$, it is noted that load eccentricity significantly increases the bending moment as shown in Figure 16. The effect of eccentricity is much more significant than the effect of scour. Applying lateral load at ground surface leads to negative and positive bending moment while load eccentricity causes

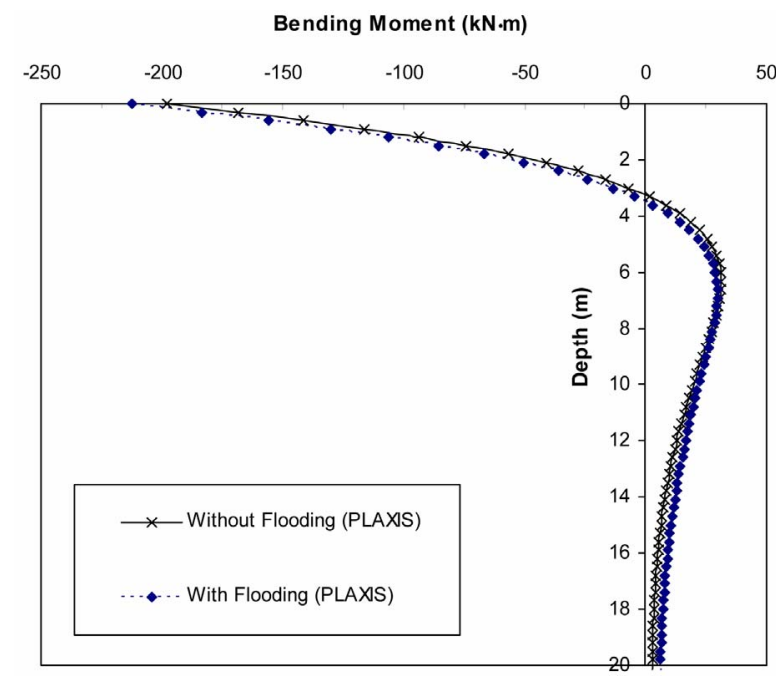

Figure 14. Bending moment computed from FEM considering the flooding condition $(\mathrm{F}=100 \mathrm{kN})$.

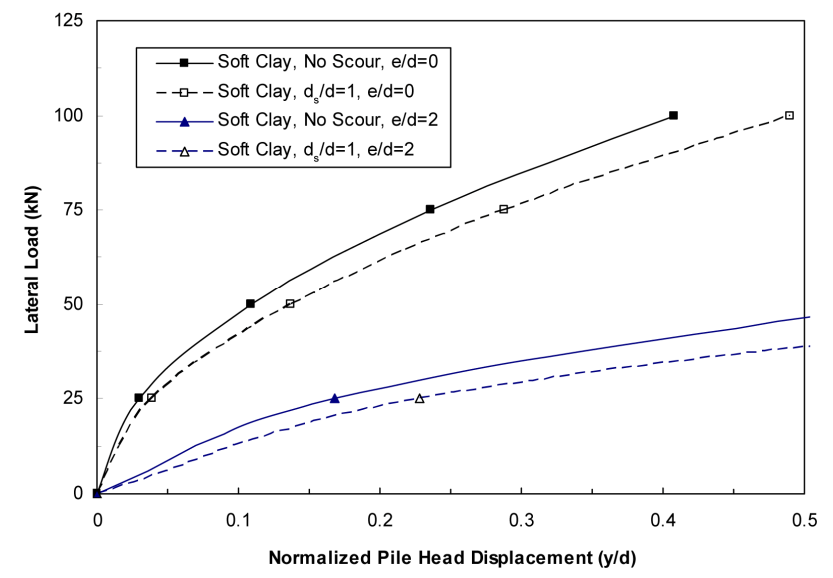

Figure 15. Lateral load versus normalized pile head displacement considering load eccentricity and scour.

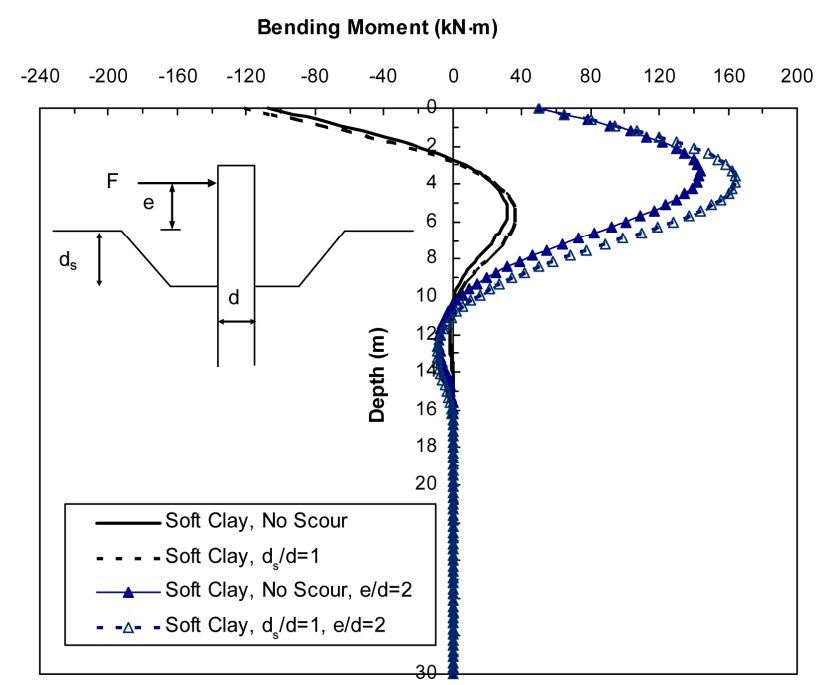

Figure 16. Effect of load eccentricity and scour on the bending moment along pile length $(F=50 \mathrm{kN})$. 
an increase in the maximum positive bending moment. While considering scour, maximum bending moment increases from about $144 \mathrm{kN} \cdot \mathrm{m}$ to $164 \mathrm{kN} \cdot \mathrm{m}$ (i.e., increase by about $14 \%$ ).

\section{Conclusions}

Based on numerical modeling of scour around single piles installed in sandy and clayey soils, it was found that scour has a significant impact on piles installed in sand and a less significant impact on piles installed in clay. The following conclusions are drawn:

For sandy soils:

1) Ultimate lateral capacity for piles subjected to global scour can be about $45 \%$ of the ultimate lateral capacity of piles without scour.

2) Ultimate lateral capacity for piles subjected to global scour is found to be about $50 \%$ to $70 \%$ of ultimate lateral capacity of piles subjected to local scour depending on the scour hole dimension.

3 ) If scour depth ranges between one to 3 pile diameters $\left(\mathrm{d}_{\mathrm{s}} / \mathrm{d}=1\right.$ to 3$)$, the pile head displacement increases by about $37 \%$ to $155 \%$ compared to that for piles without scour.

4) The bending moment in piles with scour increases by about $48 \%$ to $60 \%$ in comparison with the same loading conditions in piles without scouring. The increase in bending moment due to scour can require piles with larger pile rigidity or higher grades to ensure that bending stresses do not exceed the pile yield stress.

5) The effect of scour is more significant if piles are subjected to large lateral load magnitudes due to the nonlinear response of pile-soil system.

6) Scour increases lateral pile head displacement by about $85 \%$ to $97 \%$ for steel piles and $97 \%$ to $106 \%$ for concrete piles compared to similar piles without scour. Also, lateral capacity of steel piles is larger than that of concrete piles for the same pile diameter.

7) Significant reduction in lateral capacity is observed when load eccentricity is applied.

For clay soils:

8) Effect of scour is more pronounced for piles installed in stiff clay compared to piles installed in soft clay.

9) Scour effect is more significant when higher loading magnitudes are applied, especially for stiff clay soils.

10) Bending moment at piles installed in stiff clay subjected to scour increases by about $7 \%$ to $42 \%$ in comparison with the same loading conditions in piles without scour.

11) Existence of water level at or above pile head provides similar results to the cases were groundwater is below the scour hole depth.

12) For load eccentricity equal to twice the pile diameter $(\mathrm{e} / \mathrm{d}=2)$, lateral pile capacity can be reduced to about $64 \%$ to $68 \%$.

13) The effect of load eccentricity on pile response is much more pronounced than the effect of scour.

\section{REFERENCES}

[1] B. M. Sumer, J. Fredsøe and N. Christiansen, "Scour around a Vertical Pile in Waves," Journal of Waterway, Port, Coastal and Ocean Engineering, Vol. 118, No. 1, 1992, pp. $15-31$. doi:10.1061/(ASCE)0733-950X(1992)118:1(15)

[2] I. N. Robertson, H. R. Riggs, S. C. Yim and Y. L. Young, "Lessons from Hurricane Katrina Storm Surge on Bridges and Buildings," Journal of Waterway, Port, Coastal and Ocean Engineering, Vol. 133, No. 6, 2007, pp. 463-483. doi:10.1061/(ASCE)0733-950X(2007)133:6(463)

[3] J. L. Briaud, H. C. Chen, K. W. Kwak, S. W. Han and F. C. K. Ting, "Multiflood and Multilayer Method and Scour Rate Prediction at Bridge Pier," Journal of Geotechnical and Geoenvironemntal Engineering, Vol. 127, No. 2, 2001, pp. 114-125. doi:10.1061/(ASCE)1090-0241(2001)127:2(114)

[4] J. L. Briaud, H. C. Chen and P. Nurtjahyo, "SRICOSEFA Method for Complex Piers in Fine-grained Soils," Journal of Geotechnical and Geoenvironemntal Engineering, Vol. 130, No. 11, 2004, pp. 1180-1191.

[5] M. Rambabu, S. N. Rao and V. Sundar, "Current-Induced Scour around a Vertical Pile in Cohesive Soil," Ocean Engineering, Vol. 30, No. 7, 2003, pp. 893-920. doi:10.1016/S0029-8018(02)00063-X

[6] Y. N. Kishore, S. N. Rao and J. S. Mani, "Influence of the Scour on Laterally Loaded Piles," The $12^{\text {th }}$ International Conference of International Association for Computer Methods and Advances in Geomechanics, Goa, 1-6 October 2008, pp. 3283-3288.

[7] Y. N. Kishore, S. N. Rao and J. S. Mani, "The Behaviour of Laterally Loaded Piles Subjected to Scour in Marine Environment," KSCE Journal of Civil Engineering, Vol. 13, No. 6, 2009, pp. 403-406. doi:10.1007/s12205-009-0403-2

[8] C. Lin, C. Bennett, J. Han and R. L. Parsons, "Scour Effects on the Response of Laterally Loaded Piles Considering Stress History of Sand," Computers and Geotechnics, Vol. 37, No. 7-8, 2010, pp. 1008-1014.

doi:10.1016/j.compgeo.2010.08.009

[9] A. W. Niedoroda, C. Dalton and R. G. Bea, "The Descriptive Physics of Scour in the Ocean Environment," Proceedings of the $13^{\text {th }}$ Offshore Technology Conference, Houston, 1981, Paper No. 4145.

[10] M. B. Zaaijer and J. Tempel, "Scour Protection: A Necessity or a Waste of Money?" Proceedings of the 43 IEA Topixal Expert Meeting, Stockholm, 2004, pp. 43-51. 


\section{Nomenclature}

$\mathrm{A}=$ pile cross section area

$\mathrm{C}_{\mathrm{u}}=$ soil Cohesion strength

$\mathrm{d}_{\mathrm{s}}=$ depth of scour

$\mathrm{d}=$ pile diameter

$\mathrm{E}_{\mathrm{p}}=$ pile modulus of elasticity

$\mathrm{E}_{\mathrm{s}}=$ soil modulus of elasticity

$\mathrm{F}=$ shear force (lateral load)

$\mathrm{I}_{\mathrm{p}}=$ pile moment of inertia
$\mathrm{L}=$ pile length

$\mathrm{L}_{\mathrm{sb}}=$ distance between base scour hole extent and pile

$\mathrm{L}_{\mathrm{st}}=$ distance between top scour hole extent and pile

$\mathrm{y}=$ pile head displacement

$\gamma_{\mathrm{s}}=$ soil unit weight

$v_{s}=$ Poisson's ratio of soil

$\phi=$ soil internal friction

$\mathrm{V}_{\mathrm{s}}=$ soil shear wave velocity

$\varepsilon_{50}=$ strain at $50 \%$ of maximum stress 